\title{
Effect of Megacal a Calcium based Micronutrient Formulation on Quality and Yield of Apple
}

\author{
Z.A. Bhat, T.R. Rather, A. Raouf. Malik*, R.H.S. Raja and Syed Sami Ullah
}

Ambri Apple research Station, Sher-e-Kashmir University of Agricultural Sciences and Technology of Kashmir, Shalimar, Srinagar, Jammu and Kashmir 190025, India

*Corresponding author

\section{A B S T R A C T}

\begin{tabular}{|l|}
\hline Ke y w o r d s \\
Apple, Calcium, \\
micronutrient \\
Sprays, Quality, \\
Yield
\end{tabular}

The present investigation aimed at evaluating the importance of ca based nutrient sprays viz., the Bio-efficacy of Megacal containing $\mathrm{Ca}, \mathrm{Mg}, \mathrm{K}, \mathrm{Zn}$, Iron and $\mathrm{Cu}$, as organic product. The sprays were used on apple cv. Red Delicious for a period of two years at farmers' field in district Shopian during 2016 and 2017. Healthy trees of uniform age (20 years) were selected. Cultural practices and plant protection measures were uniform for all the selected trees, irrespective of treatments. On each tree four branches from four sides were marked, for different flower and fruit observation measures. The experimental design was RBD with four replications in each treatment. T1 comprised of MegaCal basal application@1 kg per tree and spray @ 2ml/litre at petal fall, walnut stage and Fruit Development stage 1 . In $\mathrm{T} 2$ the concentration was raised to $3 \mathrm{ml} / \mathrm{litre}$ and was again sprayed at petal fall, walnut stage and Fruit Development stage 1 with basla application as $1 \mathrm{~kg}$ per tree. While as T3 comprised of three sprays@ $4 \mathrm{ml} /$ litre with sprays again at petal fall, walnut stage and Fruit Development stage. Results showed that different treatment had various effects on fruit set and fruit quantity and quality. The chemical had significant impact on fruit set, fruit retention, yield fruit and fruit firmness. Further it was observed that chemical sprayed at concentration $2 \mathrm{ml} / \mathrm{l}$ with basal application @ 1 kg/tree had significant impact on yield and fruit quality characteristics.

\section{Introduction}

Due to the growing needs of society to agricultural production, all focuses and tries have been to increase productions efficiency of agricultural community and many studies have been done to achieve this important goal. The apple is one of the oldest fruit known to man, and to feed him has started to the breeding and domestication (Asgharzade and Babaeian, 2012) and Paul, M.V (1999). Fruit is one of the important products of the horticulture and the highest production rate belongs to China and the US.

Kashmir is very famous for cultivation of temperate fruits and among temperate fruits apple constitutes the major portion production and area and forms a major chunk of the economy. Apple is the backbone of the rural 
economy in the Kashmir division and due to various reasons One among these limitations is the improper nutrient management especially that of essential nutrients particularly $\mathrm{Ca}, \mathrm{B}, \mathrm{Mg}$, Fe, $\mathrm{Zn}$ etc.

These elements are essential for plant growth, yield and fruit quality. Among these nutrients $\mathrm{Ca}$ is especially important because apples are stored for longer periods and the deficiency of calcium cannot be substituted by any other factor for the maintenance of fruit quality under storage conditions.

In order to investigate the impact of nutrient combination on yield and quality of apple present study was undertaken on apple cv. Red Delicious for a period of two years at AARC, Shopian.

\section{Materials and Methods}

The experiment was carried out at AARC for two consecutive years i.e. 2016 and 2017.The study was carried out on 20-22 years old apple plants cv. Red Delicious. Trees of uniform size, age and vigor were selected. The selected plants were labeled and grouped into four treatments having three replications under randomized block design. Plants were kept under uniform cultural operation including irrigation, fertilization, insect-pests and disease control during the entire period of investigation.

Calculated dose of product Megacal containing nutrients viz $\mathrm{Ca}, \mathrm{Mg}, \mathrm{Zn} \mathrm{Mn}, \mathrm{K}, \mathrm{B}$ and $\mathrm{Cu}$, were applied as per the treatment details given in the table below at different stages of crop growth.

\begin{tabular}{|c|c|c|c|c|}
\hline Variety & : & \multicolumn{3}{|c|}{ Red Delicious } \\
\hline Year & : & \multicolumn{3}{|c|}{ 2016and 2017} \\
\hline Replications & : & \multicolumn{3}{|c|}{4} \\
\hline Treatments & : & \multicolumn{3}{|l|}{3} \\
\hline Age of plants & : & \multicolumn{3}{|c|}{20 years } \\
\hline $\begin{array}{l}\text { Stage of crop at the time } \\
\text { of application }\end{array}$ & : & \multicolumn{3}{|c|}{ Basal dose, Petal fall, walnut stage, Fruit Development -I } \\
\hline Method of application & : & \multicolumn{3}{|c|}{ Soil/ Foliar spray } \\
\hline \multirow[t]{5}{*}{ Treatment details } & \multirow[t]{5}{*}{ : } & S.No. & Treatment/stage of crop & Conc. \\
\hline & & $\mathrm{T}-1$ & $\begin{array}{l}\text { Basal application } \\
\text { Petal fall } \\
\text { Walnut stage } \\
\text { Fruit Dev-1 }\end{array}$ & $\begin{array}{l}1 \mathrm{~kg} / \text { tree } \\
2 \mathrm{ml} / 1 \\
2 \mathrm{ml} / 1 \\
2 \mathrm{ml} / 1\end{array}$ \\
\hline & & $\mathrm{T}-2$ & $\begin{array}{l}\text { Basal application } \\
\text { Petal fall } \\
\text { Walnut stage } \\
\text { Fruit Dev-1 }\end{array}$ & $\begin{array}{l}1 \mathrm{~kg} / \text { tree } \\
3 \mathrm{ml} / 1 \\
3 \mathrm{ml} / 1 \\
3 \mathrm{ml} / 1\end{array}$ \\
\hline & & $\mathrm{T}-3$ & $\begin{array}{l}\text { Basal application } \\
\text { Petal fall } \\
\text { Walnut stage } \\
\text { Fruit Dev-1 }\end{array}$ & $\begin{array}{l}1 \mathrm{~kg} / \mathrm{tree} \\
4 \mathrm{ml} / 1 \\
4 \mathrm{ml} / 1 \\
4 \mathrm{ml} / 1\end{array}$ \\
\hline & & $\mathrm{T} 4$ & Control & --- \\
\hline Observations recorded & : & \multicolumn{3}{|c|}{$\begin{array}{l}\text { 1. Fruit Set } 2 \text {. Fruit retention } 3 \text {. Yield } 4 \text {. Fruit Weight } 5 \text {. Fruit Size } \\
\text { 6. fruit color } 7 \text {. Firmness } 8 \text {. TSS and } 9 \text {. Phtotoxicity }\end{array}$} \\
\hline
\end{tabular}


Fruits were harvested in the month of October. Observations were recorded on different parameters of the vegetative, fruit physical and chemical characters. Total number of the fruits from an individual plant was counted at the time of harvesting. Yield from individual plants were calculated by weighing all the fruit of a single plant and expressed in $\mathrm{kg} /$ plant. Five fruits from each replication were taken and weighed on the digital weighing balance and averaged value was worked out and expressed in grams. Same five fruits were taken for fruit length and breadth using a Vernier Caliper and averaged value was worked out and expressed in millimeters $(\mathrm{mm})$. Total soluble solids $\left({ }^{\circ} \mathrm{B}\right)$ were measured with the help of refractometer. The data generated from these investigations were appropriately computed, tabulated and were analyzed by applying Randomized Block Design Factorial (RBD).

\section{Results and Discussion}

\section{Effect of Ca based nutrient formulation (Megacal) on fruit set and yield of Apple cv. Red Delicious}

\section{Fruit set (\%) and fruit retention (\%)}

The perusal of data revealed significant difference in fruit set percentage among the different treatments. During course of testing, maximum fruit set of $34.57 \%$ was recorded with treatment $\mathrm{T} 2$ which was followed by treatment T3 (31.62\%). T1, T2 and T3 were at par with each other, however, minimum fruit set of $24.53 \%$ was obtained in control. Maximum fruit retention percentage $(82.23 \%)$ was obtained in T2 which was highly significant than control. It was followed by T1 and T3 that where at par with each other, while as minimum fruit retention of $70.38 \%$ was obtained in control. Nitrogen supply of pollen required proteins for movement during pollen tube and reaching the egg and increase the lifespan of the egg, Increases the effective time of pollination and embryo sac formed been strong and increase the percentage of fruit set and stimulate the growth of pollen tubes and in enzyme activity, protein synthesis and breakdown and tryptophan biosynthesis have contributed and thereby increases the percentage of fruit set. Boron, causing pollen germination and pollen tube growth and have many roles in metabolic activities Zinc is a micronutrient element that is needed for the formation of the desired size for fruit production. This element is part of the carbonic anhydraz enzyme is present in all photosynthetic tissues that is required for chlorophyll biosynthesis. $\mathrm{Zn}$ is also role in in the synthesis of tryptophan that is a precursor for the synthesis of auxin (Hewitt, 1993). And hence, this research is consistent with tens of researches, related to the use of nitrogen, Boron and Zinc to fruit set. For example William (1991) reported that in peach trees, zinc deficiency causes the production of small fruits, deformation and make the quality is too low. Bybordi and Malakouti (2005) also reported effect of Zinc boric acid and zinc sulfate on the fruit set significantly.

\section{Fruit weight (g)}

The highest fruit weight of $150.44 \mathrm{~g}$ was recorded with treatment T2and was significantly different from that of control which recorded least fruit weight of $139.52 \mathrm{~g}$. However, T1, T2 and T3 were at par with each other. Results of this experiment, is according to reports by Hassan et al (2010) that the use of liquid organic and other effective materials, increased Fruit weight and yield compared to control.

\section{Yield (kg/tree)}

During the period of investigation, highest fruit yield of $75.65 \mathrm{~kg} /$ tree was obtained with the treatment $\mathrm{T} 2$, followed by treatment $\mathrm{T} 3$ 
which recorded fruit yield of $71.39 \mathrm{~kg} /$ tree, while the control recorded the yield of 65.84 $\mathrm{kg} /$ tree. Further the data presented in table 1 revealed that, all the treatments were at par with each other and differed significantly from control w.r.t yield. Similar results regarding the effect of $\mathrm{Zn}$ in increased fruit set of almonds (Malakooti and Tehranian, 2000) $20 \%$ increase in fruit set in grapes sprayed with zinc sulphate (Malakouti and Ziaeian, 2000), positive results in increasing fruit set and seed formation and yields Such as wheat, potatoes, apricots, apples, peaches, tomatoes, cucumbers and grapes in pilot projects in the country with sprayed zinc sulphate (Malakouti and Tabatabaie, 1999) have been reported.

\section{Effect of Ca based Nutrient formulation} (Megacal) on fruit size, colour, firmness and TSS (B) of Apple cv. Red Delicious

\section{Fruit length (mm) and fruit breadth ( $\mathrm{mm})$}

The longest fruit of $69.00 \mathrm{~mm}$ was recorded with T2 which was at par with T1 and T3, whereas the control (Water spray) had fruit of length $60.12 \mathrm{~mm}$. The data presented in table revealed that there is significant increase in fruit length with the chemical treatments in comparison with control. During the investigation, fruit breadth of $67.30 \mathrm{~mm}$ was obtained with treatment $\mathrm{T} 2$ and $66.59 \mathrm{~mm}$ with treatment $\mathrm{T} 1$, whereas the control (Water spray) had fruit of least breadth $59.84 \mathrm{~mm}$. The data presented in table 2 , revealed that that there is significant increase in fruit breadth with the chemical treatments during course of testing in comparison with control. Calcium has a significant influence on the characteristics of plasma colloids and their osmotic potential. It promotes longitudinal growth and cell division in meristematic tissues (Pepó and Gyıri, 2005). It has a specific effect on cell elongation and differentiation, it influences the structure and permeability of cell membranes (Pepó et al., 2005).

\section{Fruit Colour (\%) and Fruit Firmness (lbs)}

Maximum fruit colour was observed with lower concentration of chemical. T1 recorded $92.08 \%$ which was at par with $\mathrm{T} 2$, however T3 had least fruit colour $(86.32 \%)$ which was at par with control $(87.01 \%)$.

The data revealed that the chemical sprays resulted in increased fruit firmness of 13.52, 13.38lbsand 13.24 with $\mathrm{T} 3, \mathrm{~T} 2$ and $\mathrm{T} 1$ respectively, whereas, control had significantly low fruit firmness of $10.25 \mathrm{lbs}$. The pooled data presented in table 2, revealed that treated fruits had maximum fruit firmness than untreated fruits indicating a positive impact of chemical in enhancing the fruit firmness which may be attributed to the increased $\mathrm{Ca}$ content due to sprays. As a secondary consequence deficiency of boron has been found to decrease the strength of cell walls (Mirkó, 1978).

TSS $\left({ }^{0} \mathbf{B}\right)$

The perusal of data revealed that maximum TSS of $14.94 \mathrm{OB}$ and $14.89{ }^{0} \mathrm{~B}$ were obtained with lower conc. of chemical. However higher conc reduced the TSS $\left(12.32{ }^{0} \mathrm{~B}\right)$ which was lower than that obtained in control $\left(13.28^{0} \mathrm{~B}\right)$. These results are consistent with the results of Smith (1997) reported that, with increasing used boron concentration, citric acid and vitamin $\mathrm{C}$ in fruit juice reduced and apparently, total solution solids of fruit juice, are not affected by boron concentration.

\section{Phytotoxicity}

No phototoxic symptoms were observed during the course of investigation on fruit or plant. 
Table.1 Effect of Ca based Nutrient formulation (Megacal) on fruit set and yield of Apple cv. Red Delicious

\begin{tabular}{|c|c|c|c|c|}
\hline Treatment & Fruit Set (\%) & $\begin{array}{l}\text { Fruit retention } \\
(\%)\end{array}$ & $\begin{array}{l}\text { Fruit Weight } \\
\text { (g) }\end{array}$ & $\begin{array}{l}\text { Yield/ plant } \\
(\mathrm{kg})\end{array}$ \\
\hline $\mathbf{T}_{1}$ & 32.23 & 80.15 & 148.68 & 74.88 \\
\hline $\mathbf{T}_{2}$ & 34.57 & 82.23 & 150.44 & 75.65 \\
\hline $\mathbf{T}_{\mathbf{3}}$ & 31.62 & 79.89 & 148.87 & 71.39 \\
\hline $\mathbf{T}_{4}$ & 24.53 & 70.38 & 139.52 & 65.84 \\
\hline $\mathrm{CD}_{0.05}$ & 3.21 & 2.43 & 3.08 & 3.69 \\
\hline
\end{tabular}

Table.2 Effect of Ca based Nutrient formulation (Megacal) on fruit size, colour , firmness and TSS(OB) of Apple cv. Red Delicious

\begin{tabular}{|c|c|c|c|c|c|}
\hline \multirow{2}{*}{$\begin{array}{l}\text { Treatment } \\
\mathrm{T}_{1}\end{array}$} & \multicolumn{2}{|c|}{ Fruit Size $(\mathrm{mm}) \mathbf{L B}$} & \multirow{2}{*}{$\begin{array}{l}\text { Fruit Colour } \\
(\%)\end{array}$} & \multirow{2}{*}{$\begin{array}{l}\text { Fruit firmness } \\
\text { (lbs) }\end{array}$} & \multirow{2}{*}{$\begin{array}{l}\text { TSS }\left({ }^{\mathbf{0}} \mathbf{B}\right) \\
14.94\end{array}$} \\
\hline & 68.66 & 66.59 & & & \\
\hline $\mathbf{T}_{2}$ & 69.00 & 67.30 & 88.18 & 13.38 & 14.89 \\
\hline $\mathbf{T}_{3}$ & 67.97 & 65.75 & 86.32 & 13.52 & 12.32 \\
\hline $\mathbf{T}_{4}$ & 60.12 & 59.84 & 87.01 & 10.25 & 13.28 \\
\hline $\mathrm{CD}_{0.05}$ & 0.37 & 0.24 & 2.65 & 0.08 & 0.54 \\
\hline
\end{tabular}

In conclusion, results showed that different treatment had various effects on fruit set and fruit quantity and quality. The chemical had significant impact on fruit set, fruit retention, yield fruit and fruit firmness. That theca based multi nutrient chemical sprayed at concentration $2 \mathrm{ml} / \mathrm{l}$ with basal application@ $1 \mathrm{~kg} /$ tree had significant impact on yield and fruit quality characteristics. At low concentration the results are encouraging and hence $2 \mathrm{ml} / \mathrm{l}$ shall be economical to use to the farming community and at the same time they can harvest the benefits.

\section{References}

Asgharzade, A., Babaeian, M. (2012). Foliar application of calcium borate and micronutrients effects on some characters of apple fruits in Shirvan region, Annals of Biological Research, 3 (1): 527-533.

Bybordi, A., Malakuti, M.J. (2005). Effects of foliar applications of nitrogen, boron, and zinc on fruit set and the some quality of almonds, Pajouhesh \& Sazandegi, 67: 32-40 (In Farsi).

Hassan, H.S.A., Sarrwy, S.M.A., Mostafa, E.M.A. (2010). Effect of foliar spraying with liquid organic fertilizer, some micro-nutrients, and giberellins on leaf mineral content, fruit set, yield, and fruit quality of "Hollywood" plum trees, Agriculture and biology journal of North America, 125: 2151-7525.

Hewitt, E. J., (1993). Essential nutrient elements for plants in plant physiology. ABS III, Academic press. 584

Malakooti, M., Tehranian, M. (2000). The role of micronutrients in increasing the yield and quality of agricultural products (micro elements with macro effects) second edition, Tarbiat Modarres University Publications (In Farsi).

Malakouti, M. J., Ziaeian, A.H. (2000). Foliar application, a new method to increase 
the efficiency of fertilizers and to achieve sustainable agriculture. Promotional magazine (1) Department of Agricultural Extension Office Planning promulgates. Council of biologically functional materials and efficient use of fertilizers and pesticides in agriculture, Karaj (In Farsi)

Malakouti, M.J., Tabatabaie, J. (1999). Proper nutrition of fruit trees, Publication of agricultural education. Karaj (In Farsi)

Mirkó, L. (1978). A mikroelem-tartalom, a talajtulajdonságés növényekmikroelemfelvételéneknéhán yösszefüggése. Kandidátusiértekezés, Debrecen. (in Hungarian)

Paul, M.V.(1999). Fertilizing temperate tree fruit and Nut crops at home, Publication of Univercity of Californi
Pepó, Péter - Gyıri, Z. (2005): A Study of the Yield Stability of Winter Wheat Varieties - Cereal Research Communications. 33. (4). 769

Pepó, Péter - Sipos, P. - Gyıri, Z. (2005): Effects of Fertilizer Application on the Baking Quality of Winter Wheat Varieties in a Long Term Experiment under Continental Climatic Conditions in Hungary - Cereal Research Communications. 33(4): 825.

Smith, A.W. (1997). A Gardener's Handbook of Plant Names: Their Meanings and Origins, Dover Publications.

William, F. B. (1991). Nutrient deficiencies and toxicities in crop plant, Publication of College of Agricultural and Natural Resources Texas Tech. University Lubbock

\section{How to cite this article:}

Bhat, Z.A., T.R. Rather, A. Raouf. Malik, R.H.S. Raja and Syed Sami Ullah. 2019. Effect of Megacal a Calcium based Micronutrient Formulation on Quality and Yield of Apple. Int.J.Curr.Microbiol.App.Sci. 8(06): 983-988. doi: https://doi.org/10.20546/ijcmas.2019.806.119 